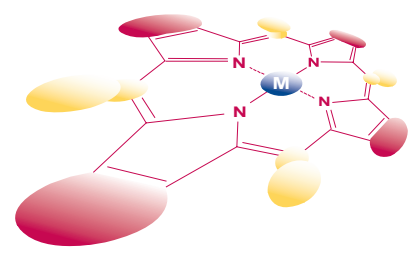

\title{
Manganese and iron tetraphenylporphyrin-catalyzed oxidation of a cardanol derivative (hydrogenated tert-butylcardanol)
}

\author{
Pietro Tagliatesta ${ }^{*}$, Claudia Crestini ${ }^{\mathrm{a}}$, Raffaele Saladino ${ }^{*}$, Veronica Neri $^{\mathrm{b}}$, Paolino \\ Filippone $^{\mathrm{c}}$, Chiara Fiorucci ${ }^{\mathrm{C}}$ and Orazio A. Attanasi ${ }^{\mathrm{C}}$
}

a Dipartimento di Scienze e Tecnologie Chimiche, University of Rome "Tor Vergata", 00133 Rome, Italy

' ${ }^{\mathrm{b}}$ Unita' INFM, Dipartimento A.B.A.C, University of Tuscia, 01100 Viterbo, Italy

${ }^{\mathrm{c}}$ Centro di Studio delle Sostanze Naturali, University of Urbino, 61029 Urbino, Italy

Received 24 September 2001

Accepted 20 December 2001

\begin{abstract}
Manganese and iron 2,6-disubstituted meso-tetraphenylporphyrins, bearing halogen atoms on the $\beta$-positions, have been used as catalysts for the oxidation of a cardanol derivative (hydrogenated tertbutylcardanol), using iodosilbenzene or hydrogen peroxide as oxygen atom donors. The reaction products can be correlated to the catalyst structure and to the nature of the oxidants. Copyright (C) 2002 Society of Porphyrins \& Phthalocyanines.
\end{abstract}

KEYWORDS: porphyrins, oxidation, catalysis, cardanol, environmentally friendly.

\section{INTRODUCTION}

Cardanol is a mixture of 3- $n$-pentadecylphenol, 3-npentadeca-8-enylphenol, 3- $n$-pentadeca-8,11-dienylphenol, and 3- $n$-pentadeca-8,11,14-trienylphenol, the main component of the roasted "cashew nut shell liquid" (CNSL), apart from cardol and anacardic acid [1]. CNSL is derived as a side-product from the mechanical processing (hot bath process) of the cashew nut of Anacardium occidentale L. [2-4]. Since world-wide cashew nut production is nearly 500,000 tons per year, CNSL is available in large amounts and may represent both a dangerous pollutant source and a low-cost widely available and renewable raw material, for obtaining pure cardanol. Cardanol is a useful starting material in fine chemical processes, particularly in the developing countries which produce the cashew nuts (India, Brazil) [2]. Cardanol and its derivatives may be used as antioxidants and, in general, as stabilisers against light, air and heat for several organic materials, e.g. flavours, foods, lubricants, polymers, and rubbers [5-10]. Moreover, CNSL extracts show antibacterial [11-12], antifungal [13] and antitumoral activities [14]. Recently, the antioxidant activity of cardanol derivatives was found to be comparable to that of commercial products, such as 2,6-di-tert-butyl-4methylphenol (BHT) and 2,6-di-tert-butyl-4-

*Correspondence to: Pietro Tagliatesta, e-mail: pietro.tagliatesta@uniroma2.it - Raffaele Saladino, email:saladino@unitus.it methoxyphenol (DBHA) [15].

The molecular structure of the cardanol derivative 4 (hydrogenated tert-butylcardanol), used as starting material in this study, is reported in Fig. 1. Quinonoid derivatives of natural phenols are ubiquitous in nature and show biological activities [16]. In particular, it has been proposed that the role of some alkyl and alkenyl cardanol derivatives might depend on the in vivo oxidative conversion to the corresponding benzoquinones [17].<smiles>CCCCCC(C)(C)c1ccc(C(C)(C)C)c(O)c1</smiles>

\section{4}

Fig. 1. The molecular structure of tert-butylcardanol

Several procedures are described in the literature for the synthesis of quinones, including Fremy's salt [17], cerium(IV) derivatives, ammonium nitrate [18-19], lead tetraacetate [20-22] and transition metal compounds [23], such as Co or Mn complexes [24]. However, most of these procedures require stoichiometric, noncatalytic experimental conditions and are not environmentally sustainable or show poor selectivity. 
We have recently reported that methylrhenium trioxide $\left(\mathrm{MeReO}_{3}, \mathrm{MTO}\right)$, a potent and useful catalyst for the activation of hydrogen peroxide [25-30], can be used for the synthesis of ortho- and para-benzoquinones of cardanol derivatives [31]. Among the general catalytic systems developed in the past for the synthesis of phenols and quinones, synthetic metalloporphyrins were successfully used [32-33]. The so-called third generation catalysts, consisting of the iron or manganese $\beta$-halogenated 2,6 disubstituted mesotetraphenylporphyrins, have been shown to be the most promising in the hydroxylation of electron-rich aromatic rings [34-35]. With the aim to find new biomimetic procedures for the conversion of cardanol derivatives to the corresponding quinones, we report here our results on the oxidation of $\mathbf{4}$ with several porphyrins as catalysts.

The catalysts used for this work were $\mathrm{Mn}\left[\left(\mathrm{Cl}_{16}\right) \mathrm{TDMPP}\right] \mathrm{Cl}, \mathbf{1}, \mathrm{Mn}\left[\left(\mathrm{Cl}_{8}\right) \mathrm{TDCPP}\right] \mathrm{Cl}, \mathbf{2}$, and $\mathrm{Fe}\left[\left(\mathrm{Cl}_{16}\right) \mathrm{TDMPP}\right] \mathrm{Cl}, \mathbf{3}$ where $\left(\mathrm{Cl}_{16}\right) \mathrm{TDMPP}$ is the dianion of $2,3,7,8,12,13,17,18$-octachloro5,10,15,20-tetrakis-(3',5'-dichloro-2',6'-dimethoxyphenyl)porphyrin and $\left(\mathrm{Cl}_{8}\right) \mathrm{TDCPP}$ is the dianion of $2,3,7,8,12,13,17,18$-octachloro-5,10,15,20-tetrakis(2',6'-dichlorophenyl)porphyrin. The molecular structures of the catalysts are reported in Fig. 2.

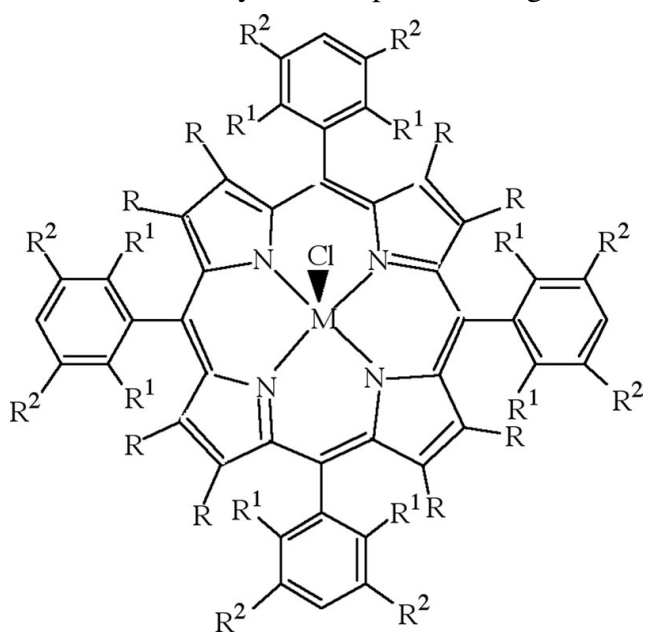

$$
\begin{array}{ll}
\mathrm{Mn}\left[\left(\mathrm{Cl}_{16}\right) \text { TDMPP }\right] \mathrm{Cl} \mathrm{R}=\mathrm{R}^{2}=\mathrm{Cl} & \mathrm{R}^{1}=\mathrm{OCH}_{3} \mathrm{M}=\mathrm{Mn} \\
\mathrm{Mn}\left[\left(\mathrm{Cl}_{8}\right) \text { TDCPP }\right] \mathrm{Cl}, \mathrm{R}=\mathrm{R}^{1}=\mathrm{Cl} & \mathrm{R}^{2}=\mathrm{H} \quad \mathrm{M}=\mathrm{Mn} \\
\mathrm{Fe}\left[\left(\mathrm{Cl}_{16}\right) \mathrm{TDMPP}\right] \mathrm{Cl} \mathrm{R}=\mathrm{R}^{2}=\mathrm{Cl} & \mathrm{R}^{1}=\mathrm{OCH}_{3} \quad \mathrm{M}=\mathrm{Fe}
\end{array}
$$

Fig. 2. Molecular structures of the catalysts

\section{EXPERIMENTAL}

\section{General}

Descriptions of analytical instruments and ${ }^{1} \mathrm{H}$ NMR and IR spectrometers have been previously published [36]. Melting points were obtained on a Reichert Kofler apparatus and are uncorrected. Electron impact mass spectra were recorded on a VG 70/250S spectrometer with an electron beam of $70 \mathrm{eV}$. FAB mass spectra were recorded on a VG-Quattro instruments using $m$ nitrobenzyl alcohol (NBA) as matrix. Microanalyses were performed with a Carlo Erba 1106 analyzer. GCMS analysis were performed on a HP 5971 mass- selective detector equipped with an HP 5890 III gaschromatograph.

Chromatographic purifications were performed on columns packed with Merck silica gel, 230-400 mesh, for flash technique. Thin-layer chromatography was carried out using Merck Kiesegel 60 F254 plates. All reagents and solvents were of the highest grade.

\section{Synthesis}

Free base porphyrins were synthesized according to literature procedures [34-35, 37-38]. The manganese and iron derivatives were synthesised as reported in the literature [39].

2-Tert-butyl-5- $n$-pentadecylphenol, (hydrogenated tert-butylcardanol) $\mathbf{4}$, was prepared from distilled cardanol by hydrogenation of the olefinic double bonds in the side chain and subsequent tert-butylation with MTBE as previously reported $[1,5]$.

General procedure for the oxidation of 2-tertbutyl-5- $n$-pentadecylphenol, 4 .

To a solution of $4,(1.0 \mathrm{mmol})$ in $\mathrm{CH}_{2} \mathrm{Cl}_{2}(5 \mathrm{ml})$ or $\mathrm{CH}_{2} \mathrm{Cl}_{2} / \mathrm{CH}_{3} \mathrm{CN}(1: 1 \mathrm{v} / \mathrm{v}, 5 \mathrm{ml})$, the appropriate porphyrin, $\mathrm{Mn}\left[\left(\mathrm{Cl}_{16}\right) \mathrm{TDMPP}\right] \mathrm{Cl}, \mathrm{Mn}\left[\left(\mathrm{Cl}_{8}\right) \mathrm{TDCPP}\right] \mathrm{Cl}$, and $\mathrm{Fe}\left[\left(\mathrm{Cl}_{16}\right) \mathrm{TDMPP}\right] \mathrm{Cl}(0.05 \mathrm{mmol})$ was added under magnetic stirring in the presence of $\mathrm{H}_{2} \mathrm{O}_{2}(2.0 \mathrm{mmol})$ or $\mathrm{PhIO}(2.0 \mathrm{mmol})$. The reaction mixture was stirred at the desired temperature $\left(25^{\circ} \mathrm{C}\right)$ for $6 \mathrm{hrs}$ and then diluted with ethyl acetate $(50 \mathrm{ml})$ and $\mathrm{H}_{2} \mathrm{O}(3 \mathrm{ml})$. The excess of primary oxidant was decomposed by adding a little $\mathrm{MnO}_{2}$. After filtration, the organic layer was washed with brine $(2 \times 10 \mathrm{ml})$, dried over $\mathrm{Na}_{2} \mathrm{SO}_{4}$, and the solvent was evaporated under reduced pressure. The products were obtained by chromatographic purification, giving acceptable to good yields and were identified by spectroscopic analyses, mass spectroscopy and comparison with authentic samples.

2-tert-Butyl-5-n-pentadecylbenzo-1, 4-quinone, (5). Powder; mp 51-53 ${ }^{\circ} \mathrm{C}$ (AcOEt). $\delta_{\mathrm{H}}\left(\mathrm{CDCl}_{3}\right): 6.53(1 \mathrm{H}, \mathrm{s}, \mathrm{CH}), 6.42(1 \mathrm{H}, \mathrm{t}, J 1.4, \mathrm{CH})$, $2.33\left(2 \mathrm{H}, \mathrm{t}, \mathrm{J}\right.$ 7.5, $\left.\mathrm{CH}_{2} \mathrm{C}=\mathrm{CH}\right), 1.45 \quad(2 \mathrm{H}, \quad \mathrm{m}$, $\left.\mathrm{CH}_{2} \mathrm{CH}_{2}\right), 1.24\left(9 \mathrm{H}, \mathrm{s}, 3 \mathrm{CH}_{3}\right), 1.22\left(24 \mathrm{H}, \mathrm{m}, 12 \mathrm{CH}_{2}\right)$, $0.84\left(3 \mathrm{H}, \mathrm{t}, J\right.$ 5.8, $\left.\mathrm{CH}_{3}\right) . \delta_{\mathrm{C}}\left(\mathrm{CDCl}_{3}\right): 188.64(\mathrm{q})$, 187.97 (q), 155.63 (q), 147.89 (q), 134.39 (t), 131.69 $(\mathrm{t}), 34.96(\mathrm{q}), 31.88(\mathrm{~s}), 29.63(\mathrm{~s}), 29.46(\mathrm{~s}), 29.31(\mathrm{p})$, $29.14(\mathrm{~s}), 28.21(\mathrm{~s}), 27.72(\mathrm{~s}), 22.65(\mathrm{~s}), 14.10(\mathrm{p})$; $\mathrm{m} / \mathrm{z}$ (EI) $374\left(\mathrm{M}^{+}\right)$.

1-tetradecanol, (6). Powder, m.p. $39{ }^{\circ} \mathrm{C}$, b.p. $289{ }^{\circ} \mathrm{C} ; v_{\max } / \mathrm{cm}^{-1}(\mathrm{KBr}) 1450,2850,2920,3500$; $\delta_{\mathrm{H}}\left(\mathrm{CDCl}_{3}\right): 0.87\left(3 \mathrm{H}, \mathrm{m}, \mathrm{CH}_{3}\right), 1.20\left(22 \mathrm{H}, \mathrm{m}, \mathrm{CH}_{2}\right)$, $1.80\left(2 \mathrm{H}, \mathrm{m}, \mathrm{CH}_{2}\right), 3.76\left(2 \mathrm{H}, \mathrm{m}, \mathrm{CH}_{2}\right) . \delta_{\mathrm{C}}\left(\mathrm{CDCl}_{3}\right)$ : 62.98 (s), 32.82 (s), 31.95 (s), 29.66 (s), 29.49 (s), 29.39 (s), 25.79 (s), 22.71 (s), 14.11 (t); $\mathrm{m} / z$ (EI) 214 $\left(\mathrm{M}^{+}\right)$.

\section{RESULTS AND DISCUSSION}

2-tert-Butyl-5- $n$-pentadecylphenol, 4, (1 mmol), was treated with $\mathrm{PhIO}(2.0 \mathrm{mmol})$ or $\mathrm{H}_{2} \mathrm{O}_{2}(2.0 \mathrm{mmol})$ in $\mathrm{CH}_{2} \mathrm{Cl}_{2}(5 \mathrm{ml})$ or $\mathrm{CH}_{2} \mathrm{Cl}_{2} / \mathrm{CH}_{3} \mathrm{CN}$ mixture $(1: 1 \mathrm{v} / \mathrm{v} ; 5$ 
ml) at $25{ }^{\circ} \mathrm{C}$ in the presence of catalytic amounts of the appropriate metalloporphyrin, $\mathbf{1}, \mathbf{2}$ or $\mathbf{3}$.

Control experiments consisting of running the oxidation of 4 with $\mathrm{PhIO}$ or $\mathrm{H}_{2} \mathrm{O}_{2}$ in the absence of catalyst were performed. In the case of $\mathrm{H}_{2} \mathrm{O}_{2}$, less than $2 \%$ conversion of $\mathbf{4}$ takes place under otherwise identical reaction conditions. With $\mathrm{PhIO}$ in $\mathrm{CH}_{2} \mathrm{Cl}_{2}$ the 2-tert-butyl-5-n-pentadecylbenzo-1,4-quinone $\mathbf{5}$ was obtained as the only recovered product, in low conversion and yield (Scheme 1, Table 1, entry 1). When the oxidation of 4 with $\mathrm{PhIO}$ in $\mathrm{CH}_{2} \mathrm{Cl}_{2}$ was performed in the presence of $\mathrm{Mn}\left[\left(\mathrm{Cl}_{16}\right) \mathrm{TDMPP}\right] \mathrm{Cl}$, compound 5 was obtained in $60 \%$ yield, in addition to 1-tetradecanol, $\mathbf{6}$ as a side-product, and unreacted substrate (Scheme 1, Table 1, entry 2). The same reaction performed with a stoichiometric amount of PhIO $(1.0 \mathrm{mmol})$ afforded 5 in lower conversion and yield $(49 \%$, and $38 \%$, respectively). Moreover, the oxidation of 4 with $\mathrm{PhIO}$ in a $\mathrm{CH}_{2} \mathrm{Cl}_{2} / \mathrm{CNCH}_{3}$ mixture in the presence of $\mathbf{1}$ gave $\mathbf{5}$ and $\mathbf{6}$ in yields similar to that previously obtained with $\mathrm{CH}_{2} \mathrm{Cl}_{2}$ as solvent (Table 1 , entry 3). In accordance with the mechanism previously proposed for the oxidation of $\mathbf{4}$ with methylrhenium trioxide, it is reasonable to suggest that the reaction proceeds through the selective formation of a reactive arene oxide intermediate and subsequent ring opening, causing dehydration and further oxidation to $\mathbf{5}$ [31].
The presence of $\mathbf{6}$ as a side product was not expected. Even if we have not studied in detail the mechanism of the reaction, the oxidation of the benzylic position to give the intermediate " $A$ " is a possible side-process under our experimental conditions (Scheme 2). Further side-chain over-oxidation processes, such as a Bayer-Villiger - like rearrangement - may be responsible for the formation of $\mathbf{6}$. In fact, it has been reported that $\beta$-halogenated metalloporphyrins give some overoxidation reactions of hydrocarbon residues [40]. The intermediate "A" was not recovered under our experimental conditions.

This hypothesis is almost in part confirmed by the detection, using GC-MS analysis, of traces of 3hydroxy-4-tert-butylbenzoic acid, which is a product of benzylic oxidation. The low amount of this sideproduct is probably due to a further oxidation of the phenol moiety to high polar ring-opened muconic acid derivatives [41]. The same reaction performed with $\mathrm{H}_{2} \mathrm{O}_{2}$ showed the highest conversion but a low selectivity and compounds $\mathbf{5}$ and $\mathbf{6}$ were obtained in $43 \%$ and $51 \%$ yields, respectively (Table 1 , entry 3 ). The oxidation of $\mathbf{4}$ was further performed both with $\mathrm{PhIO}$ and $\mathrm{H}_{2} \mathrm{O}_{2}$ in the presence of catalyst 2 . In the first case, the para-benzoquinone 5 was obtained in 59\% yield as the main product, in addition to the alcohol $\mathbf{5}$ in $13 \%$ yield (Scheme 1, Table 1, entry 5 ).

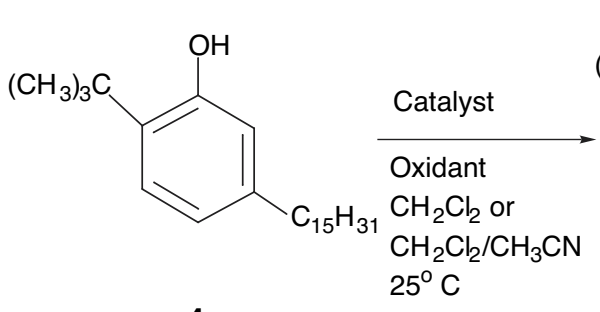

4

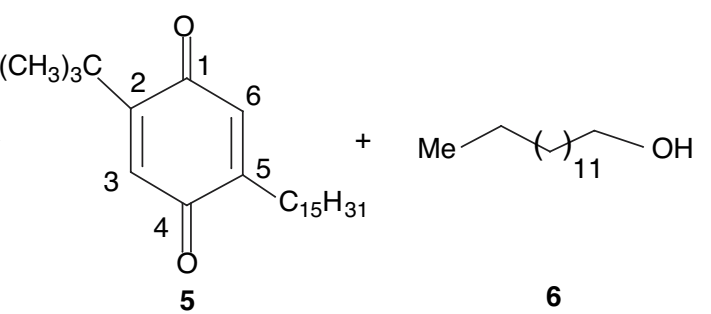

Scheme 1.

Table 1. Conversions and yields in the oxidation of 4 with $\mathrm{PhIO}$ and $\mathrm{H}_{2} \mathrm{O}_{2}$ catalyzed by manganese and iron porphyrins ${ }^{\mathrm{a}}$

\begin{tabular}{ccccccc}
\hline Entry & Catalyst & Oxidant & Solvent & Product(s) & $\begin{array}{c}\text { Conversion } \\
\text { b }\end{array}$ & $\begin{array}{c}\text { Yield }^{\text {c }}(\%) \\
\text { Ratio }[\mathbf{5} / \mathbf{6}]\end{array}$ \\
\hline 1 & absent & $\mathrm{PhIO}$ & $\mathrm{CH}_{2} \mathrm{Cl}_{2}$ & $\mathbf{5}$ & 9 & 97 \\
2 & $\mathbf{1}$ & $\mathrm{PhIO}$ & $\mathrm{CH}_{2} \mathrm{Cl}_{2}$ & $\mathbf{5 , 6}$ & 67 & $60(10)[6]$ \\
3 & $\mathbf{1}$ & $\mathrm{PhIO}$ & $\mathrm{CH}_{2} \mathrm{Cl}_{2} / \mathrm{CH}_{3} \mathrm{CN}$ & $\mathbf{5 , 6}$ & 63 & $59(8)[7.4]$ \\
4 & $\mathbf{1}$ & $\mathrm{H}_{2} \mathrm{O}_{2}$ & $\mathrm{CH}_{2} \mathrm{Cl}_{2} / \mathrm{CH}_{3} \mathrm{CN}$ & $\mathbf{5 , 6}$ & 72 & $43(51)[0.8]$ \\
5 & $\mathbf{2}$ & $\mathrm{PhIO}$ & $\mathrm{CH}_{2} \mathrm{Cl}_{2}$ & $\mathbf{5 , 6}$ & 65 & $59(13)[4.5]$ \\
6 & $\mathbf{2}$ & $\mathrm{H}_{2} \mathrm{O}_{2}$ & $\mathrm{CH}_{2} \mathrm{Cl}_{2} / \mathrm{CH}_{3} \mathrm{CN}$ & $\mathbf{5 , 6}$ & 68 & $47(45)[1.0]$ \\
7 & $\mathbf{1}$ & $\mathrm{H}_{2} \mathrm{O}_{2}{ }^{\mathrm{d}}$ & $\mathrm{CH}_{2} \mathrm{Cl}_{2} / \mathrm{CH}_{3} \mathrm{CN}$ & $\mathbf{5}$ & 61 & 95 \\
8 & $\mathbf{2}$ & $\mathrm{H}_{2} \mathrm{O}_{2}{ }^{\mathrm{d}}$ & $\mathrm{CH}_{2} \mathrm{Cl}_{2} / \mathrm{CH}_{3} \mathrm{CN}$ & $\mathbf{5}$ & 58 & 91 \\
10 & $\mathbf{3}$ & $\mathrm{PhIO}^{2}$ & $\mathrm{CH}_{2} \mathrm{Cl}_{2}$ & $\mathbf{5 , 6}$ & 80 & $33(29)[1.1]$ \\
& $\mathbf{3}$ & $\mathrm{H}_{2} \mathrm{O}_{2}$ & $\mathrm{CH}_{2} \mathrm{Cl}_{2} / \mathrm{CH}_{3} \mathrm{CN}$ & $\mathbf{5 , 6}$ & 76 & $28(22)[1.3]$
\end{tabular}

${ }^{\text {a } C o n d i t i o n s: ~} \mathrm{CH}_{2} \mathrm{Cl}_{2}$ or $\mathrm{CH}_{2} \mathrm{Cl}_{2} / \mathrm{CH}_{3} \mathrm{CN}(1: 1 \mathrm{v} / \mathrm{v}, 5 \mathrm{ml})$, catalytic amount of porphyrin, 2.0 equiv./mol. of oxidant, $25^{\circ} \mathrm{C}, 6 \mathrm{hrs}$. ${ }^{\mathrm{b}}$ Conversions of $\mathbf{1}$ was evaluated by mass balance on recovered substrate. ${ }^{\mathrm{c}}$ Yields of $\mathbf{5}$ and $\mathbf{6}$ based on the converted substrate. ${ }^{\mathrm{d}}$ Reaction carried out in the presence of excess of imidazole. 


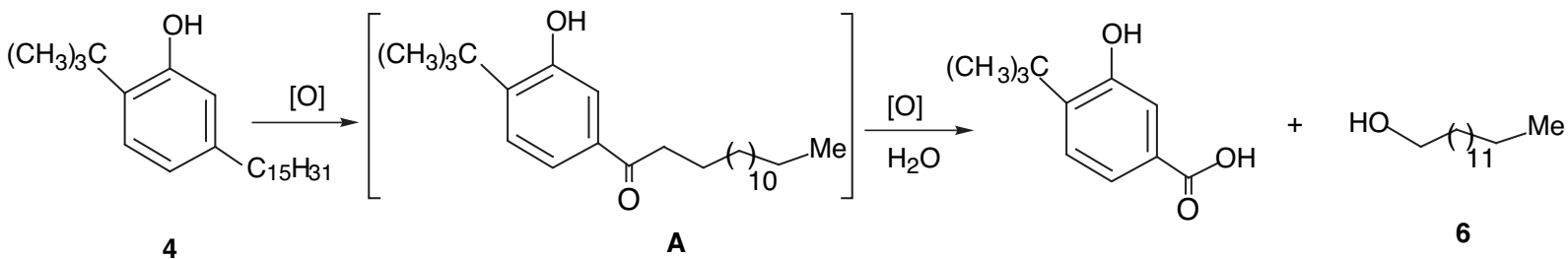

Scheme 2.

With $\mathrm{H}_{2} \mathrm{O}_{2}$ as primary oxidant, compounds 5 and $\mathbf{6}$ were obtained in comparable yield (Table 1 , entry 6). A different pathway was observed when the oxidation of 4 with 1 and $\mathrm{H}_{2} \mathrm{O}_{2}$ was performed in the presence of an excess of imidazole in a $\mathrm{CH}_{2} \mathrm{Cl}_{2} / \mathrm{CH}_{3} \mathrm{CN}$ mixture $(1: 1$ $\mathrm{v} / \mathrm{v} ; 5 \mathrm{ml})$. Under these experimental conditions, the para-benzoquinone $\mathbf{2}$ was obtained in $95 \%$ yield as the only recovered product, in addition to unreacted substrate (Table 1, entry 7). Similar results were obtained with 2 and $\mathrm{H}_{2} \mathrm{O}_{2}$ in $\mathrm{CH}_{2} \mathrm{Cl}_{2} / \mathrm{CH}_{3} \mathrm{CN}$ mixture $(1: 1 \mathrm{v} / \mathrm{v} ; 5 \mathrm{ml})$ (Table 1 , entry 8$)$.

Finally, the oxidation of 4 with $\mathrm{PhIO}$ in $\mathrm{CH}_{2} \mathrm{Cl}_{2}$ in the presence of the iron porphyrin 3 showed the best conversion reaction ( $80 \%$ ) but only low yields, 33\% and 29\% respectively, in both compounds 5 and $\mathbf{6}$ (Table 1, entry 9). The smaller yield of 5 obtained with $\mathbf{3}$ as catalyst with respect to manganese porphyrins $\mathbf{1}$ and 2 , might be due to ring-opened, water soluble, products formed by overoxidation. Moreover, complex reaction mixtures were obtained when the isolated quinone 5 was used as a substrate in the presence of a small excess of oxidants $(1.2 \mathrm{mmol})$. On the basis of these data, manganese tetraphenylporphyrins show a high catalytic activity for the oxidation of 4 . In the presence of PhIO and using catalysts $\mathbf{1}$ or $\mathbf{2}$, the parabenzoquinone $\mathbf{5}$ can be obtained in acceptable conversion and yield. The reaction is selective and the orto-quinone (not shown) was not recovered from the reaction mixture, probably because the steric hindrance of the $n$-pentadecyl side-chain. Irrespective of the porphyrin used in the transformation, the oxidation performed with $\mathrm{H}_{2} \mathrm{O}_{2}$ proceeds mainly by a side-chain oxidation to the alcohol 6.

Notably, in the presence of imidazole as an axial ligand, compound $\mathbf{5}$ becomes the only recovered product. The effect of imidazole on the catalytic efficiency of the manganese porphyrins is well-known from the literature [24-25]. In the current study with $\mathrm{H}_{2} \mathrm{O}_{2}$, the presence of the imidazole drives the reaction to a larger selectivity. Unfortunately, the iron tetraphenylporphyrin $\mathbf{3}$ does not show a selective catalytic activity using either $\mathrm{PhIO}$ or $\mathrm{H}_{2} \mathrm{O}_{2}$ as oxidants (Table 1, entries 9 and 10). In conclusion, we have shown that metalloporphyrins convert selectively a cardanol derivative into a valuable fine-chemical under environmentally friendly experimental conditions.

\section{Acknowledgements}

The support of the Italian MURST (Progetti di ricerca di rilevante interesse nazionale) and CNR is gratefully acknowledged.

\section{REFERENCES}

1. Tyman JHP. Synthetic and Natural Phenols; Elsevier: Amsterdam, 1996.

2. Cashew Nut Shell Liquid Patents. In $A$ Compilation of Patents on Cashew Nut Shell Liquid Taken in the United States, India, United Kingdom, and Japan, 1964.

3. Attanasi OA, Buratti S and Filippone P. Chim. Ind. (Milan, Italy) 1996; 78: 693-696.

4. Tyman JHP. Chem. Soc. Rev. 1979; 8: 499-537.

5. Attanasi OA, Filippone P and Balducci S. Gazz. Chim. Ital. 1991; 121: 487-489.

6. Antony R, Pillai CKS and Scariah KJ. J. Appl. Polym. Sci. 1990; 41: 1765-1775.

7. Attanasi OA, Filippone $\mathrm{P}$ and Grossi M. Phosphorus, Sulfur Silicon Relat. Elem. 1988; 35: 63-65.

8. Menon ARR, Pillai CKS and Nando GB. J. Appl. Polym. Sci. 1994; 51: 2157-2164.

9. Ghatge ND and Khisti RS. J. Polym. Mater. 1989; 6: 145-149.

10. Short EL, Tychopoulos V and Tyman JPH. J. Chem. Technol. Biotechnol. 1992; 53: 389-396.

11. Himejima M and Kubo I. J. Agric. Food Chem. 1991; 39: 418-421.

12. de Morais SM, Beezer AE, Ashby J and Bolton R. Int. J. Pharm. 1990; 66: 107-110.

13. Adawadkar PD and El Sohly MA. Fitoterapia 1981; 52: 129-135.

14. Chen J, Zhang YH, Wang LK, Sucheck SJ, Snow AM and Hecht SM. Chem. Commun. (Cambridge, U. K.) 1998: 2769-2770.

15. Amorati R, Pedulli GF, Valgimigli L, Attanasi OA, Filippone P, Fiorucci C and Saladino R. J. Chem. Soc., Perkin Trans. 2 2001: 2142-2146.

16. Monks TJ, Hanzlik RP, Cohen GM, Ross D and Graham DG. Toxicol. Appl. Pharmacol. 1992; 112: 2-16.

17. Balint AV, Dawson JH and Dawson CR. Anal. Biochem. 1975; 66: 340-352.

18. Zimmer H, Lankin DC and Horgan SW. Chem. Rev. (Washington, D. C.) 1971; 71: 229-246.

19. Kende AS and Ebetino FH. Tetrahedron Lett. 1984; 25: 923-926.

20. Brimble MA, Hodges $\mathrm{R}$ and Stuart SJ. Tetrahedron Lett. 1988; 29: 5987-5990.

21. Balanikas G, Hussai N, Amin S and Hecht SS. $J$. Org. Chem. 1988; 53: 1007-1010.

22. Fischer A and Henderson GN. Synthesis 1985: 641-643.

23. Hansen DW, Jr., Pappo R and Garland RB. J. Org. Chem. 1988; 53: 4244-4253.

24. Barton DHR, Finet JP and Thomas M. Tetrahedron 1988; 44: 6397-6406. 
25. Ganeshpure PA, Sudalai A and Satish S. Tetrahedron Lett. 1989; 30: 5929-5932.

26. Fujibayashi S, Nakayama K, Nishiyama $Y$ and Ishii Y. Chem. Lett. 1994: 1345-1348.

27. Adam W, Hermann WA, Lin J and Saha-Moller CR. J. Org. Chem. 1994; 59: 8281-8283.

28. Herrmann WA, Fischer RW, Rauch MU and Scherer W. J. Mol. Catal. A: Chem. 1994; 86: 243-266.

29. Espenson JH, Pestovsky O, Huston P and Staudt S. J. Am. Chem. Soc. 1994; 116: 2869-2877.

30. Herrmann WA, Fischer RW, Scherer W and Rauch MU. Angew. Chem., Int. Ed. 1993; 32: 1157-1160.

31. Saladino R, Neri V, Mincione E, Marini S, Coletta M, Fiorucci $\mathrm{C}$ and Filippone P. J. Chem. Soc., Perkin Trans. 1 2000: 581-586.

32. Meunier B. Chem. Rev. (Washington, D. C.) 1992; 92: 1411-1456.

33. Mansuy D. Coord. Chem. Rev. 1993; 125: 129141.
34. Artaud I, Ben Aziza K, Chopard C and Mansuy D. Chem. Commun. (Cambridge, U. K.) 1991: 3133.

35. Artaud I, Ben Aziza K and Mansuy D. J. Org. Chem. 1993; 58: 3373-3380.

36. Saladino R, Crestini C, Mincione E, Costanzo G, Di Mauro E and Negri R. Bioorg. Med. Chem. 1997; 5: 2041-2048.

37. Autret M, Ou Z, Antonini A, Boschi T, Tagliatesta $\mathrm{P}$ and Kadish KM. J. Chem. Soc., Dalton Trans. 1996: 2793-2797.

38. Rocha Gonsalves AMDA, Varejao JMTB and Pereira MM. J. Heterocycl. Chem. 1991; 28: 635-640.

39. Adler AD, Longo FR, Kampas F and Kim J. J. Inorg. Nucl. Chem. 1970; 32: 2443-2445.

40. Baciocchi E, Boschi T, Galli C, Lapi A and Tagliatesta P. Tetrahedron 1997; 53: 4497-4502.

41. Artaud I, Grennberg H and Mansuy D. Chem. Commun. (Cambridge, U. K.) 1992: 1036-1038. 